\title{
Secrecy and the Study of International History: Missing Dimension in Turkish Foreign Policy
}

\author{
Egemen Bezci \\ Massey University
}

\begin{abstract}
The study of international history largely depends on an exploitation of hitherto unexplored data. The sources of these data could vary from national archives to private papers to semi-structured interviews and so on. An examination of the historiography of Turkish Foreign Policy requires the employing of a rigorous methodology to unearth novel data to feed into current academic debates. Students of international history should be advised of possible logistic and methodological flaws and obstacles in the process. This article examines these logistical and methodological obstacles to conducting archival research for historiographical studies.
\end{abstract}

Keywords: Historiography, secrecy, diplomacy, international history, intelligence, Turkish foreign policy

\section{Introduction}

A historiography of a country's foreign relations is generally employed to demonstrate the contesting views on the empirical events of the past, and a historiographical analysis of foreign relations is most often - and inaccurately—referred to as diplomatic history. To understand the limitations of the term diplomatic history we should initially define what diplomacy is. Doyen scholar Geoffrey Berridge defines diplomacy as "a form of artful communication between states, or through their designated agents, to conduct foreign policy without resorting to force, law or propaganda". ${ }^{1}$ Thus, any study of diplomatic history puts the state and its agents as the center of the research while sidelining other anthropogenic factors shaping global politics.

Diplomatic history, thus examines the relations between states through their agents. Such a methodology to explain global affairs ultimately limits the empirical data and critical approaches to the study of international affairs. Therefore, international history is a more accurate and comprehensive term for an historical inquiry into global affairs. An international history approach to research extends the limitations of diplomatic history by bringing in a large spectrum of empirical data ranging from environmental history to history of medicine. Such a wide interaction among related disciplines enriches the methodological strength of international history, and deconstructs diplomatic history as the main historical tool for mainstream international relations. A competent methodology for conducting international

Egemen Bezci, Visiting Scholar, Centre for Defence and Security Studies, Massey University. Email: ebbezci@gmail.com (D) https://orcid.org/0000-0002-1089-5907

1 Geoffrey Berridge, Diplomacy: Theory and Practice (Bansington: Palgrave, 2010). 
history research deals with obtaining data from primary sources such as official archives and interviews. This method of historiographical study can be applied into the study of subdisciplines pertaining to international history, such as intelligence studies, security studies and international relations.

If one considers international relations as the observable communications between anthropogenic and/or naturogenic networks of powers relations, one needs to employ an equally wide-ranging tool in order not to neglect wider casual variables for the sake of analysis. It is also important to note that the neglect of wider casual variables does not always happen due to the sake of the analysis but rather is a mere reflection of the scholar's weltanschauung (World View). This is especially true for scholars examining the history of international relations. One's weltanschauung can easily dominate the methodological rigor since there are not any established scientific ways to re-create the exact historical events to test the accuracy of any interpretation. Any interpretation of global affairs, in a Popperian sense, does not help to predict the future but endeavors to explain the past to stimulate our learning process. ${ }^{2}$

This learning process has been rather productive between the disciplines of international history and political science. Both international history and political science experienced a cross-fertilization to answer the causes and consequences of the global historical phenomenon, and further helping to develop stronger theories, including sociological geographical studies of global affairs. ${ }^{3}$ Scholars such as John Young, Richard Aldrich, Rory Cormac, Dina Rezk has already produced sound and influential research benefitting from the strengths of both disciplines. ${ }^{4}$ This multi-disciplinary method on international affairs requires collaborating various primary and secondary sources, including interviews, and archive exploitation at various sites. There are already two valuable methodological guides and contextual companions in the discipline. ${ }^{5}$ There are also ongoing reputable programmes mainly employing this methodology to investigate various conceptual questions regarding the international politics. Harvard University's Cold War Studies Project based in the Davis Center for Russian and Eurasian Studies, and the London School of Economics' Cold War Studies are the two eminent examples. Both research groups host prominent journals, respectively the Journal of Cold War Studies and Cold War History Journal.

Although there have been valuable advancements in methodological and empirical endeavors in the discipline, two flag-ship international relations departments in Turkey, namely those of Koc and Bilkent Universities, have not reflected this cutting-edge research in

Karl Popper, The Poverty Of Historicism (London: Routledge, 2002).

3 Colin Elman and Miriam Fendius Elman, "The Role Of History İn International Relations," Millennium 37, no. 2 (2008): 357-64; Kim Salamon, "What is the Use of International History?," Journal of Peace Quarterly 30, no. 4 (1993): 375-89; Colin Elman, and Miriam Fendius Elman, "Diplomatic History and International Relations Theory: Respecting Difference and Crossing Boundaries," International Security 22, no. 1 (1997): 5-21; Paul W. Schroeder, "History and International Relations Theory: Not Use or Abuse, But Fit or Misfit," International Security 22, no. 1 (1997): 64-74; Stephen Hobden, and John M. Hobson, eds., Historical Sociology of International Relations (Cambridge: Cambridge University Press, 2002); Stephen H. Haber, David M. Kennedy, and Stephen D. Krasner, "Brothers under the Skin: Diplomatic History and International Relations," International Security 22, no. 1 (1997): 34 43; Geoffrey Roberts, "History, Theory and the Narrative Turn in IR," Review of International Studies 32, no. 4 (2006): 703-14.

4 Richard J. Aldrich, The Hidden Hand: Britain, America and the Cold War Secret Intelligence (London: Overlook Books, 2001); Young, John W., and John Kent, International Relations since 1945 (Oxford: Oxford University Press, 2013); Rory Cormac, Confronting the Colonies: British Intelligence and Counterinsurgency (Oxford: Oxford University Press, 2014); Dina Rezk, "Orientalism and Intelligence Analysis: Deconstructing Anglo-American Notions of the 'Arab'," Intelligence and National Security 31, no. 2 (2016): 224-45.

5 Gordon Martel, ed. A Companion to International History 1900-2001 (Oxford: Blackwell, 2008); Marc Trachtenberg, The Craft of International History: A Guide To Method (Princeton: Princeton University Press, 2009). 
their curriculum and training. In Bilkent, core diplomatic history courses, entitled Diplomatic History I \& II, present a rather state-centric, indeed Euro-centric, and out-dated approach. The same is also true for Koc University's core course, History of Modern Diplomacy, where fundamental training lacks a comprehensive encompassing of the methods and concepts.

\section{A Know- How of International History}

I initially used a cross-bordering methodology between political science and history to examine the effect of the state of emergency on the civil-military relations in Turkey following the 1980 coup d'état. ${ }^{6}$ There were already existing theories on civil-military relations driven from sociology and/or organizational studies, however I was looking for a historical method in order to deconstruct the contesting historical views to obtain empirically useful data. As Walter Benjamin elaborates on Angelus Novus, "where we see the appearance of a chain of events, he [Angel of History] sees one single catastrophe, which unceasingly piles rubble on top of rubble and hurls it before his feet." Thus, my task was to deconstruct the witness accounts, which are either from the oppressed or the policy-making elite. A mere structuralist methodology such as looking at the national-security decision making would not yield a productive research.

In order to examine the power relations pertaining to the options and tools of the various political actors on their respective relation to the law preserving and law-making violence, I had to exploit various primary sources. These sources ranged from the minutes of the National Security Council to internal documentation of the Kurdistan Workers' Party, and to semi-structured interviews with parties to the emergency state. My first attempt to employ the international history methodology to examine the Turkish emergency state was rather an early effort, and did not accomplish a fair task of drawing lessons from other disciplines.

However, my initial examination of the country's security apparatus brought another important question for me to answer. What was the role and impact of the Turkish intelligence service on the country's domestic/global affairs? The existing literature on the international history of Turkey or literature on Turkish security studies had not examined the country's secret intelligence apparatus, thus yielding the existing scholarship incomplete. Therefore, a lack of necessary empirical data limited my methodology where I could not comfortably employ IR or sociological methodologies. ${ }^{8}$ I had to unearth the empirical data myself. This was rather a challenge for me since there was very little, if any, giants on whose shoulders to stand. Thus, I conducted my initial methodological training with my $\mathrm{PhD}$ supervisor, Professor John W. Young from the University of Nottingham. Professor Young, as the veteran scholar of international history and the chairman of the British International History Group, advised me on how to access and analyze the primary sources. Moreover, my doctoral training at the University of Nottingham had formal methodology workshops on analyzing archival material, and conducting semi-structured interviews to obtain data for research purposes.

It is an imperative for scholars to use cutting-edge technology for their research as well. A DLSR camera and tape-recorder are standard items for this research methodology. It is also important to use an Optical Character Recognition (OCR) software that allows converting

6 Egemen B. Bezci and Güven Gürkan Öztan, "Anatomy of the Turkish Emergency State: A Continuous Reflection of Turkish Raison d'état between 1980 and 2002," Middle East Critique 25, no. 2 (2016): 163-79.

7 Walter Benjamin, On the Concept of History (Createspace Independent, 2009).

8 See, Philip Davies and Kristian C. Gustafson, eds., Intelligence Elsewhere: Spies and Espionage Outside the Anglosphere (Washington, DC: Georgetown University Press, 2013). 
images from the archives into a machine editable text file. The OCR software enables researchers of international history to directly work on the archive files rather than spending a considerable amount of time to re-type the archives from the image copies. Moreover, OCR enables the use of additional translation software to read the archives written in other languages. Also, for transcription of the interview records, it is important to use computer tools such as Transcriber to save the tremendous time of manually transcribing the records.

However, new technology cannot help overcome fundamental issues with methodology. First, a fundamental problem may lay with the issue of logistics. An examination on the international history of Turkey requires ambitious scholars to conduct research in at least five countries, namely US, UK, Belgium (NATO), Turkey and Bulgaria. Bulgaria is a peculiar case, however, since it entails the vast number of declassified archives from the former Socialist bloc, it helps to draw sources from a large spectrum to demonstrate a comprehensive analysis. This list can be quite exhaustive depending on the temporal and spatial scope of the research question. When dealing with a country like Turkey, which traditionally employs a balance of power game to prevent being a stooge in global affairs, it is important to cover as wide a variety of primary sources as possible to unveil this multifaceted foreign policy. However, conducting research in various countries requires extensive resources. Considering that the grants for social science are extremely competitive, it is imperative that one should draft a realistic budget for one's research, and be aware of its practical flaws.

The second issue is interviews. Most former practitioners and diplomats will naturally like to place themselves at the center of historical events when they recall the incidents. This is rather an important challenge since it is crucial for one to keep the record straight and not mix facts and myths. However, it is also extremely important to not challenge or correct your interviewee's recollections. The data obtained from the interviews can be later verified by collaborating with other sources. Also, it is imperative to conduct the interviews in the last stage of data collection after exhausting other primary and secondary sources, and then identifying the people pertaining to the research question.

Verification is also necessary with archive documents. The declassification process of archives varies from country to country according to their transparency and accountability policies. There is no clear declassification process in Turkey. Piles of documents pertaining to the country's contemporary history have not been released even in a redacted way. On the other hand, those countries who routinely declassify their state archives and open them to public scrutiny also suffer from a methodological flaw. The records of sensitive matters such as spying on friendly nations, conducting covert operations and domestic counter-subversion efforts are either not saved in the archives or are destroyed afterwards. Researchers should be aware that declassification does not necessarily mean that some of the archives are not destroyed or kept out of the declassification process. However, these flaws and gaps in the data collection can be overcome by using the archives in various countries. This method is called as the multi-archive study. Countries exchange information through liaison process and diplomatic communication. Moreover, the diplomatic records of any country possess countless incoming cables flowing from their diplomatic missions around the globe. These cables contain useful data with traces, and if one is lucky, the information can be substantial, to complete the missing information in other department records. Also, countries may not show the same sensitivity to each other's secrets and may thereby declassify other country's secrets obtained through liaison or diplomatic communication. For instance, the British National 
Archives declassified the bulk of Turkish material from the Second World War obtained through intelligence liaison, even though these Turkish documents are not still declassified by the Turkish archives. This neglect among countries fuels distrust between them, but it helps students and scholars of international history to obtain more data by collaborating different sources. Finally, it is important to identify legal opportunities in different national contexts to file Freedom of Information Act (FOIA) requests to the pertinent departments. FOIA requests can take years to conclude therefore it is important to adjust one's research schedule accordingly. It is useful to contact with and follow the George Washington University's Digital National Security Archive Project. ${ }^{9}$ They have been working with freedom of information requests for three decades and can be helpful for legal/technical aspects of the FOIAs.

However, still the issue of secrecy veils data and creates obstacles for archival methodology. This is particularly true in countries such as Turkey where national security has been mythicized and politicians throughout the country's history have not been welcoming to the notions of transparency and public scrutiny. Richard Aldrich points out that in circumventing the methodological hurdles due to the ongoing secrecy surrounding archives (which is particularly tighter in the Turkish case), students of international history have to "invest some time [and money] in the organic process of growing [their] own records." 10 To grow your own records, one may need to chase down auction houses, antique shops, families of deceased diplomats/officers, and even sometimes garage sales to obtain private papers of former practitioners. Since there was a tendency among Turkish officials to take a copy of the documents home (they did not perceive it as public property but rather as a report they wrote), ample numbers of official reports can appear among these papers.

However, the private papers and memoirs of the former practitioners should be handled with caution. The very issue of secrecy, as Joshua Rovner points out, may lead to a politicization by decision-makers, knitting a layer of secrecy in the formulation of foreign and national security policy. ${ }^{11}$ This politicization behind closed doors creates what Rovner calls a 'pathologic relation' between the policy-making and intelligence communities. Due to the secrecy and lack of public scrutiny of national security and foreign policy matters, these realms are open to more politicization. Thus, the politicization and pathological relationship could result in manipulation of these private papers to reflect the policy preferences. These policy preferences are not necessarily based on a consensus on national security matters but could as well reflect the political leader's domestic concerns. It is imperative for students of Turkish foreign policy to employ rigorous multi-archival methods to unearth the causations and correlations leading to and diverging from the point of critical junctures, rather than building upon the 'fixed facts' in the literature or taking for granted whatever is given in the private papers or archives. Just as the best carpenters are not necessarily the best art historians, the practitioners in a country's foreign and security policy are not the best scholars of the discipline. The students of international history should handle the primary material with caution and put a safe distance between themselves and the policy-making to keep their scholarly critique uncontaminated. Otherwise, as many scholars of Turkish foreign and security policy do, one may fall into the trap of 'constricting one's historical purview

\footnotetext{
9 See, National Security Archive, accessed March 5, 2017, https://nsarchive.gwu.edu/digital-national-security-archive.

${ }^{10}$ Richard J. Aldrich, "Grow your own': Cold War Intelligence and History Supermarkets," Intelligence and National Security 17, no. 1 (2002): 149.

11 Joshua Rovner, Fixing the Facts: National Security and the Politics of Intelligence (Ithaca: Cornell University Press, 2011).
} 
excluding potential causal variables'. ${ }^{12}$

Moreover, as Philip Davies argues, 'arbitrarily mixing and matching the versions of events emerging from reported evidence is simply not a viable approach' to producing a reliable conclusion in research based on multi-archive method. ${ }^{13}$ As Davies suggests, in order to have a reliable source of data for the research, one needs to employ a triangulation method, using multiple primary and published secondary sources, corroborating the information within and between these various sources. ${ }^{14}$ In doing so, students and scholars of international history can also integrate information from previously unexplored archives, not least in Turkey, to complement or challenge conclusions from previous research.

\section{Results, Flaws and Application of the Methodology}

I employed the international history methodology for my book entitled Turkish Intelligence and the Cold War: Espionage, Security and International Relations. ${ }^{15}$ This book examines the hitherto unexplored history of secret intelligence cooperation between three asymmetric partners - specifically the UK, US and Turkey - from the end of the Second World War until modern Turkey's first military coup d'état on 27 May 1960. The book shows that our understanding of the Cold War as a binary rivalry between the two blocs is too simple an approach and obscures important characteristics of cooperation among allies. To reveal a more comprehensive analysis of intelligence cooperation, the book develops a model called 'intelligence diplomacy'. Intelligence diplomacy fills the gap between conventional diplomacy and intelligence cooperation. This model explores a vital, if little understood, aspect of contemporary international relations given the prevalence of transnational threats today. Intelligence diplomacy involves negotiations and the exploitation of different aspects of joint intelligence activities, synchronized between diplomats and specialized intelligence officers. Much more than this, it also makes a new contribution to the literature of what might be called the general phenomenon of intelligence alliance and liaison as a general subject, which was important in the Cold War, but which we have also seen over decades all the way to the recent wars in Syria and Iraq. The book also shows that a pragmatic approach offers states new opportunities to protect national interests, by conducting intelligence diplomacy to influence crucial areas such as nuclear weapons and to exploit cooperation in support of their own strategic imperatives. By doing so the book not only reveals previously-unexplored origins of secret intelligence cooperation between Turkey and West, but also contributes to wider academic debates on the nature of the Cold War and also by highlighting the potential agency of weaker states in the Western Alliance. Therefore, the book shows that the strategic direction of secret intelligence was not always congruent with the Cold War.

Although there are methodological difficulties for a historical study of secret intelligence, time-consuming and patient archival research can give fruitful results. For my book I did not solely employ a strong Turkish or Western voice in my sources, but rather drew on a wide range of archives. Thus, archival sources from Turkey, the UK, US, Poland and NATO were the primary basis for the research. In particular, the Turkish State Archive's Republic

12 Dan Slater and Erica Simmons, "Informative Regress: Critical Antecedents in Comparative Politics," Comparative Political Studies 43, no. 7 (2010): 886-917.

${ }^{3}$ Philip Davies, "Spies as Informants: Triangulation and the Interpretation of Elite Interview Data in the Study of the Intelligence and Security Services," Politics 21, no. 1 (2001): 78.

14 Davies, "Spies as Informants". 2018).

${ }^{15}$ Egemen Bezci, Turkish Intelligence and the Cold War: Espionage, Security and International Relations (London: IB Tauris, 
period Council of Ministers and Prime Minister's Office series includes detailed documents on the period. Turkish parliament records, the Turkish military archives' (ATASE), were also of help. Several of these archives are open to investigation but subject to permission by the authorities. The primary contribution of these archives based in Turkey is that they demonstrate both the inner workings of the security establishment and the attitude of the political leadership concerning intelligence and foreign policy. Both of these archives are going through an ongoing cataloguing process which results in restricted access to the documents especially covering the late 1950s. However, I was able to gain access to a considerable number of intelligence estimates, memorandums, and correspondence by several private collections and papers.

In addition to the Turkish archives, declassified CIA records are open to research through the CIA Records Search Tool (CREST). The US National Archives and Records Administration's State Department Central Decimal Files and the Records of the National Security Agency/Central Security Service also held relevant documents for my research. Recently the NSA began working closely with the National Archives, thus making available for researching documents dealing with the early Cold War era. Besides the National Archives, the personal papers and official papers in the Truman and Eisenhower Libraries, and the Library of Congress include valuable materials.

The NATO archives are also going through a declassification process. The released materials particularly include relevant documents on the standardization of secret intelligence, intelligence sharing under the NATO structure and the intelligence capacity building in the member countries. NATO's Military and the Defence Committee series contain particularly useful documents pertaining to this study. However, NATO's intelligence documents go through a rather slower pace of declassification vis-à-vis other relevant archives. Therefore, the NATO archives best serve as a complementary source for that era. The Joint Intelligence Committee records, Ministry of Defence Records, Foreign Office Records and the records of the Security Service in the British National Archives also include primary documents that pertained to my research, as did some materials in the Churchill Archive Centre in Cambridge. The archives in the UK, US and NATO not only complemented the Turkish sources by providing an insight into the Western intelligence attitude, they were also essential to reflect the asymmetrical nature of the Turkish-Western intelligence diplomacy. Also, a comparative assessment of the national archives in relation to the NATO archives demonstrates the prevalence of distrust among Allies in a multilateral setting.

In addition to the Western and Turkish archives, Poland's Institute of National Remembrance recently released the Polish archives on Soviet secret intelligence operations in Turkey during the Cold War, and this has helped researchers to provide a Soviet perspective on Turkish-Western intelligence cooperation.

The CENTO archives, the Turkish Ministry of Foreign Affairs archives and the Turkish Intelligence archives, however, remain mostly closed to public access. Similarly, the NATO, CIA and the British Security Service archives offer only a limited access to their intelligence operations in cooperation with the Turkish intelligence service. As a substitute for the limited archival material on particular dimensions of secret intelligence cooperation, the private collections of, published memoirs of and interviews with ministers, officers and diplomats have been exploited to shed light on events. However, the lack of existing literature on the topic created for me a methodological obstacle for the verification and collaboration of 
primary sources.

There has been a very limited amount of scholarly work analysing the origins, content and success of the Turkish-Western intelligence alliance. The essential reason for this scarcity is the dominant attitude of scholars of Turkish international history. They tend to cover the foreign Ministry and the cabinet, seldom referring to the role of the security and intelligence machinery. ${ }^{16}$ Moreover, most studies tend to neglect the intelligence dimension of Turkish foreign policy, although it was at the core of Turkish-Western relations on issues ranging from U-2 spy planes to the covert operations in the Middle East. A small number of studies have focused on Turkish-Allied intelligence cooperation, especially activities in Turkey against the Axis forces during the Second World War. ${ }^{17}$ Therefore, my book aimed at re-shaping our understanding of contemporary history of the relationship between intelligence, foreign policy and covert action more generally, upgrading our estimation of human intelligence in the region.

The missing piece in the literature has been the role of secret intelligence in the actions of Turkey in the Western Alliance during the course of the Cold War. Although, countries such as Turkey played a crucial role in the both tactical and strategic intelligence efforts of the Western alliance, the role of secret intelligence both in the alliance structure and the general course of the Cold War in these countries has been an under-researched area. Therefore, it was essential to investigate the Turkey's secret intelligence activities in the origins and development of the Cold War to reveal how the minor powers in the Western Alliance, in this case Turkey, conducted its foreign and security policy in the pretext of the Cold War. It is also important to address how the weaker states used intelligence diplomacy to complement their lack of material capabilities to secure greater leverage in the Alliance and also greater political influence in the regions in which they are located.

Lack of previous historical or organizational research on the intelligence services outside of the Anglosphere makes the study of the Turkish case of particular interest to the field, but a problem exists in the literature dealing with the Turkish secret services. Even in the academic literature examining the topic, this literature has a tendency to blend its conclusions with a conspiracy theory of a long existing and brutal Turkish 'Deep State', which was claimed to be a clandestine informal network designed by the Turkish security services for their military patrons to shape politics and the judicial process. ${ }^{18}$ The historical evidence examined in my book suggests that the politicization of the Turkish intelligence community, in addition to the pressing international issues during the Cold War, rendered the country's intelligence apparatus as an often maverick tactical tool for the various political players in the domestic and foreign power struggles in the country. Therefore, any study of Turkish secret

16 David Alvarez, Bureaucracy and Cold War Diplomacy: The United States and Turkey 1943-1946 (Thessaloniki: Institute of Balkan Studies, 1980); Ekavi Athanassopoulou, Turkey-Anglo-American Security Interests, 1945-1952 : The First Enlargement of NATO (London: Routledge, 1999); Bruce Kuniholm, The Origins of the Cold War in the Near East: Great Power Conflict and Diplomacy in Iran, Turkey, and Greece (Princeton: Princeton University Press, 1980); Saban Halis Calis, Turkey's Cold War: Foreign Policy and Western Alignment in the Modern Republic (London: IB Tauris, 2017); Şuhnaz Yilmaz, Turkish-American Relations, 1800-1952: Between the Stars, Stripes and the Crescent (London: Routledge, 2015); Geoffrey Berridge, British Diplomacy in Turkey, 1583 to the Present: A Study in the Evolution of the Resident Embassy (Leiden: Brill, 2009); William Hale, Turkish Foreign Policy since 1774 (London: Routledge, 2012).

17 Barry Rubin, Istanbul Intrigues (New York: Pharaoh Books, 1992); Nicholas Tamkin, Britain, Turkey, and the Soviet Union, 1940-45: Strategy, Diplomacy, and Intelligence in the Eastern Mediterranean (London: Palgrave, 2009).

18 Michael Gunter, "Turkey, Kemalism, and the 'Deep State'," in Conflict, Democratization, and the Kurds in the Middle East, ed. Mehmet Gürses and David Romano (New York: Palgrave, 2014), 17-39; Mehtap Söyler, The Turkish Deep State: State Consolidation, Civil-military Relations and Democracy (London: Routledge, 2015); Ryan Gingeras, Heroin, Organized Crime, and 
intelligence, independent from the domestic and international context surrounding it, cannot provide an adequate analytical framework for the topic. Moreover, Damien Van Puyvelde and Sean Curtis' recent quantitative study on the intelligence literature, conducted by analyzing the field's two flagship journals, Intelligence and National Security and the International Journal of Intelligence and Counterintelligence, revealed that intelligence studies indeed are not diverse. ${ }^{19}$ Their findings suggest that the field is dominated by Anglo-American male researchers who work on Western-centric topics. ${ }^{20}$ Due to the lack of accumulated knowledge on the Turkish secret intelligence, which is outside of Europe but part of the Western Alliance, needs a detailed understanding of the differences and cultures of secret intelligence.

My book reveals that secret intelligence cooperation has been the backbone of the Turkish engagement with the Western Alliance. However, it does not necessarily mean that Turkish security and foreign policy solely pursued the Western alignment due to the shared threat perception with the West, namely the Soviet Union. Turkish security and foreign policy has been conducted in accordance with a blended mix of threat perceptions, meeting the domestic needs of the incumbent regime, and seeking a security commitment from the West to pursue Turkey's national imperatives, which were not necessarily the product of the Cold War bipolar world. An application of international history methodology for this book project opened up the path for future students rather than contributing to an existing school within Turkish foreign policy. Therefore, possible methodological flaws, and empirical inaccuracies in my research makes the book an initial step for future students to challenge.

\section{Final Remarks}

It is not easy to conduct a research study in an area of secrecy and historical sensitivity. Particularly in Turkey, it may be seen as almost impossible to conduct a scholarly inquiry into the country's modern secret intelligence machinery, due to the political sensitivity, lack of archives, and other pressures stemming from the political environment. However, students and scholars of international history should always keep in mind, as the veteran scholar Richard Aldrich affirms, "there are no secrets, only lazy researchers. ${ }^{21}$ This statement is exactly true when considering the fact that Christopher Andrew of Cambridge University pioneered the field back in 1985 by publishing the authoritative account of the British Intelligence Community when both primary and secondary sources were not as abundant as today. ${ }^{22}$ However, particularly in the Turkish case, one should be extra cautious given the fact that academic freedom of expression is not as guaranteed as it is in a consolidated democracy, and dealing with sensitive topics such as the country's security and defense policy, including the issue of secret intelligence, may have other legal or political consequences for scholars.

My research on the Cold War history of Turkey's secret intelligence community is far from an authoritative account. It is just an initial step to open up a path for future scholars, and to contribute to wider historiographical debates by unearthing original empirical data. While my research tries to explain the character and origins of the Turkish intelligence diplomacy during the early Cold War, there are limitations that it cannot yet overcome.

\footnotetext{
19 Damien Van Puyvelde and Sean Curtis, “'Standing on the Shoulders of Giants': Diversity and Scholarship in Intelligence Studies," Intelligence and National Security 31, no. 7 (2016): 1040-54.

${ }_{20}$ Puyvelde and Curtis, "Standing on the Shoulders of Giants"”.

21 Richard J. Aldrich, GCHQ: The Uncensored Story of Britain's Most Secret Intelligence Agency (London: Harper Press, 2010).

${ }^{22}$ Christopher M. Andrew, Secret Service: The Making of the British Intelligence Community (London, Heinemann, 1985)
} 
First, some of the British Prime Minister's files dealing with Turkey remain closed to the public. ${ }^{23}$ This lack of access limits our understanding as to the degree of Turkish endeavours to manipulate to their own advantage frictions between the Americans and the British after the Suez Crisis. Furthermore, it is also not known what kind of policies, if any, the British developed to keep Ankara in their orbit to prevent increasing Turkish dependence on America during the early Cold War. It would be also interesting to reveal whether the British used any methods of intelligence diplomacy against Turkey to limit the loss of British leverage on the country, including the use of GCHQ SIGINT bases on Turkey, and psychological warfare to counter-balance rising American influence. Another limitation of this research concerns access to Turkish archives. The limited and disorganized public disclosure of the Turkish archives limits this research to assess to what extent the politicization of the Turkish security community hampered its relations with the West, and fragmented the Turkish security community in general. ${ }^{24}$ Access to the relevant archives would reveal the domestic dimension of Turkish intelligence diplomacy to a much greater extent.

In a related manner, but not necessarily depending on access to primary sources, my research has only limited insight into how domestic politics and leadership in Turkey, the US, and the UK affected intelligence diplomacy. There are valuable studies focusing on how security and intelligence policies related to decision makers on both sides of the Atlantic. ${ }^{25}$ Yet the scope of my research is limited in a way to provide an in-depth investigation of the effect of the domestic politics and the character of the political leadership on the conduct of Turkish secret intelligence. Moreover, in this way my research does not set out to provide a comprehensive contribution to theories concerning international relations, such as the Alliance theory. These are some examples of prominent flaws in my research that I hope the future students of international history may contribute to with a more solid methodological and empirical approach.

23 For instance, numerous Freedom of Information Requests and the Appeals to the Public Records Office to release, "PREM 11/279: Prime Minister's Office: Correspondence and Papers, 1951-1964 - TURKEY" have been rejected by the authorities.

${ }^{24}$ Freedom of Information Requests to reveal the minutes of the Turkish National Security High Council by the Turkish State Archives, and also to the National Security Council has been rejected.

${ }_{25}$ See, R. Aldrich and R. Cormac, The Black Door: Spies, Secret Intelligence, and British Prime Ministers (London, 2016); D. C. Unger, The Emergency State: America's Pursuit of Absolute Security At All Costs (New York: The Penguin Press, 2012). 


\section{Bibliography}

Aldrich, Richard J. GCHQ: The Uncensored Story of Britain's Most Secret Intelligence Agency. London: Harper Press, 2010.

—. "Grow Your Own': Cold War Intelligence and History Supermarkets.” Intelligence and National Security 17, no. 1 (2002): 135-52.

. The Hidden Hand: Britain, America and the Cold War Secret Intelligence. London: Overlook, 2001.

Aldrich, Richard J., and Rory Cormac. The Black Door: Spies, Secret Intelligence, and British Prime Ministers. London: William Collins, 2016.

Alvarez, David. Bureaucracy and Cold War Diplomacy: The United States and Turkey 1943-1946. Thessaloniki: Institute of Balkan Studies, 1980.

Andrew, Christopher M. Secret Service: The Making of the British Intelligence Community. London: Heinemann, 1985.

Athanassopoulou, Ekavi. Turkey-Anglo-American Security Interests, 1945-1952: The First Enlargement of NATO. London: Routledge, 1999.

Benjamin, Walter. On the Concept of History. Createspace Independent, 2009.

Berridge, Geoffrey. British Diplomacy in Turkey, 1583 to the Present: A Study in the Evolution of the Resident Embassy. Leiden: Brill, 2009.

- Diplomacy: Theory and Practice. Bansington: Routledge, 2010.

Bezci, Egemen. Turkish Intelligence and the Cold War: Espionage, Security and International Relations. London: IB Tauris, 2018.

Bezci, Egemen B., and Güven Gürkan Öztan. "Anatomy of the Turkish Emergency State: A Continuous Reflection of Turkish Raison d'état between 1980 and 2002." Middle East Critique 25, no. 2 (2016): 163-79.

Calis, Saban. Turkey's Cold War: Foreign Policy and Western Alignment in the Modern Republic. London: IB Tauris, 2017.

Cormac, Rory. Confronting the Colonies: British Intelligence and Counterinsurgency. Oxford: Oxford University Press, 2014

Davies, Philip, and Kristian C. Gustafson, eds. Intelligence Elsewhere: Spies and Espionage outside the Anglosphere. Washington: Georgetown University Press, 2013.

Davies, Philip. "Spies as Informants: Triangulation and the Interpretation of Elite Interview Data in the Study of the Intelligence and Security Services." Politics 21, no. 1 (2001): 73-80.

Elman, Colin, and Miriam Fendius Elman. "Diplomatic History and International Relations Theory: Respecting Difference and Crossing Boundaries.” International Security 22.1 (1997): 5-21.

Elman, Colin, and Miriam Fendius Elman. "The Role of History in International Relations.” Millennium 37, no. 2 (2008): 357-64.

Gingeras, Ryan. Heroin, Organized Crime, and the Making of Modern Turkey. Oxford: Oxford University Press, 2014.

Gunter, Michael. "Turkey, Kemalism, and the 'Deep State'." In Conflict, Democratization, and the Kurds in the Middle East, edited by M.Gürses and D. Romano, 17-39. New York: Palgrave, 2014.

Haber, Stephen H., David M. Kennedy, and Stephen D. Krasner. "Brothers under the Skin: Diplomatic History and International Relations.” International Security 22, no. 1 (1997): 34-43.

Hale, William. Turkish Foreign Policy since 1774. London: Routledge, 2012.

Hobden, Stephen, and John M. Hobson, eds. Historical Sociology of International Relations. Cambridge University Press, 2002.

Kuniholm, Bruce R. The Origins of the Cold War in the Near East: Great Power Conflict and Diplomacy in Iran, Turkey, and Greece. Princeton: Princeton University Press, 1980.

Martel, Gordon, ed. A Companion to International History 1900-2001. Oxford: Blackwell, 2008. 
Popper, Karl Raimund. The Poverty of Historicism. London: Routledge, 2002.

Rezk, Dina. "Orientalism and Intelligence Analysis: Deconstructing Anglo-American Notions of the 'Arab'.” Intelligence and National Security 31, no. 2 (2016): 224-45.

Roberts, Geoffrey. "History, Theory and the Narrative Turn in IR.” Review of International Studies 32, no. 4 (2006): 703-14.

Rovner, Joushua. Fixing the Facts: National Security and the Politics of Intelligence. Ithaca: Cornell University Press, 2011.

Rubin, BM. Istanbul Intrigues (New York: Pharaoh Books, 1992).

Salamon, Kim. "What is the Use of International History?" Journal of Peace Quarterly 30, no. 4 (1993): 375-89.

Schroeder, Paul W. "History and International Relations Theory: Not Use or Abuse, But Fit or Misfit." International Security 22, no. 1 (1997): 64-74.

Slater, Dan, and Erica Simmons. "Informative Regress: Critical Antecedents In Comparative Politics." Comparative Political Studies 43, no. 7 (2010): 886-917.

Söyler, Mehtap. The Turkish Deep State: State Consolidation, Civil-military Relations and Democracy. London: Routledge, 2015.

Tamkin, Nicholas. Britain, Turkey, and the Soviet Union, 1940-45: Strategy, Diplomacy, and Intelligence in the Eastern Mediterranean. London: Palgrave, 2009.

Trachtenberg, Marc. The Craft of International History: A Guide to Method. Princeton: Princeton University Press, 2009.

Unger, David. The Emergency State: America's Pursuit of Absolute Security at All Costs. New York: Penguin, 2012.

Van Puyvelde, Damien, and S. Curtis. "'Standing on the Shoulders of Giants': Diversity And Scholarship in Intelligence Studies.” Intelligence and National Security 31, no. 7 (2016): 1040-54.

Yilmaz, Suhnaz. Turkish-American Relations, 1800-1952: Between the Stars, Stripes and the Crescent. London: Routledge, 2015.

Young, John W., and John Kent. International Relations since 1945. Oxford: Oxford University Press, 2013. 